\title{
TEACHING MADURA LOCAL CONTENT LITERACY ON PRESERVICE SCIENCE TEACHER USING LWIS MODEL
}

\author{
Mochammad Yasir ${ }^{1}$, Ana Yuniasti Retno Wulandari ${ }^{2}$ \\ ${ }^{1,2}$ Natural Science Education Study Program, Trunojoyo University \\ Bangkalan, 69162, Indonesian \\ Iidlmy.354@gmail.com, ${ }^{2}$ ana.wulandari@trunojoyo.ac.id \\ Accepted: October 15, 2020 \\ Published: October 31, 2020 \\ DOI: https://doi.org/1921107/jps.v7i2.8445
}

\begin{abstract}
Several previous studies have shown that students have difficulty integrating ethnoscience into science learning. Students are more likely to be introduced to the basic concepts of ethnoscience without involving how to integrate ethnoscience into science learning. The impact is that students' scientific literacy is low. This is what underlies researchers to apply the Local Wisdom Integrated Science (LWIS) learning model by using local Madurese content to train students' scientific literacy. The aim of this study was to evaluate differences in student scientific literacy after implementing the LWIS learning model in ethnoscience learning with local Madurese content. The method used was pre-experimental study with one group pretest-posttest design. When the study was carried out in the even semester of the 2019/2020 academic year by taking 22 students via purposive sampling technique as a sample of all students in class 6 A of science education, Trunojoyo University, Madura. Analysis of data using descriptive statistics and paired sample $t$ test. The results showed that there were different in the scientific literacy of the students using the LWIS learning model before and after studying ethnoscience with local Madurese material. The entire LWIS syntax helps train students' scientific literacy by including self-awareness of the importance of local Madurese content as a learning context. Ethnoscience can be integrated into science learning through the STEAM approach. The contribution of STEAM to the LWIS learning model and self-awareness is very significant in developing ethnoscience learning for local Madurese content from elementary, middle, and tertiary level.
\end{abstract}

Keywords: ethnoscience, local Madurese content, LWIS, scientific literacy

\footnotetext{
${ }^{1}$ Corresponding Author
} 


\section{Introduction}

The world is actually faced with a transition from Industrial Revolution (R.I.) 4.0 to Civilization (5.0). The 4.0 to 5.0 period architecture is based on Sustainable Development Goals / SDGs (Nastiti, 2020). Era of R.I. 4.0, Society 5.0, and SDGs emphasize the importance of competency. Scientific literacy is one of the competencies needed in this era (Trilling dan Fadel, 2009; Schwab, 2017).

Scientific literacy is important to solve the environmental problems. In both literature and experimental research the problem is discussed and explored in depth. There's substance, scientific awareness, expertise and attitudes in science literacy (Bybee, 2011; Genc, 2015). This underlines the connection between local content cultures such as Madura and scientific literacy.

The local content of Madura as content, scientific knowledge, competence and attitudes can be taught as if science were learned through a scientific approach (Bozpolat, 2016; Mumthas \& Suneera, 2015; Ameyaw, 2011). The scientific approach helps to create understanding among students through 5 stages including observing, questioning, collecting information/trying, reasoning/associating, making conclusions and communicating (Savelsbergh, De Jong, \& Ferguson-Hessler, 2011; Villagonzalo, 2014). Students are encouraged to seek knowledge from various sources through engaging cognitive processes that stimulate intellectual development.

One of the learning resources that can be used comes from the local cultural traditions, in this case the Madurese community. For example, rituals are performed by the Madurese community in Bulan Syuro in the rocking lake at sea. Tasik rockat is to provide offerings in the form of food, etc. with the aim of providing feedback on the increase in fish catch of fishermen. The Madurese people's opinion which is used as belief is not necessarily true (indigenous knowledge). Knowledge of belief can be studied as a science if it can be proven scientifically through experiments or literature studies (scientific knowledge).

The illustration of the example above shows the relationship between public knowledge and science in the form of science content, scientific method, scientific process skills, which is called ethnoscience. Ethnoscience examines the influence of public opinion on socio-culture as part of the result of real behavior in creating changes in their environment (Sudarmin, 2014; Yuliana, 2017).
Therefore, ethnoscience can be integrated in science learning.

The reality in the field shows that students have difficulty integrating ethnoscience into science learning. In integrating culture and science, students are more likely to be exposed to the basic concepts of ethnoscience as material and scientific knowledge without requiring how to incorporate ethnoscience into science learning (Parmin \& Fibriana, 2019; Genc, 2015). Integration of ethnoscience into science learning requires competence and attitude in reviewing literature and conducting experiments and learning models (Jurecki \& Wader, 2012; Yuenyong \& Narjaikaew, 2009). This results in low student scientific literacy.

From ethnoscience studies, learning theory, the development of the R.I. 4.0, Society 5.0, SDGs, and current problems, it is necessary to develop innovative learning models. The innovative learning model offered is Local Wisdom Integrated Science (LWIS). This learning model was developed based on the learning theory of behaviourism, social, cognitivism, constructivism involving pedagogy and andragogy, integrating community cultural knowledge in science is expected to have an instructional and accompanying impact (Mungmachon, 2013; Pornpimon, et al., 2014).

The expected instructional impact is in the form of strengthening the brain in thinking, especially the skills to communicate the integration of indigenous knowledge in scientific scientific knowledge. The expected accompanying impact is the learning experience for students, especially as science teacher candidates to study, integrate, and preserve local culture (Bybee, 2011).

The Local Wisdom Integrated Science (LWIS) learning model has 5 syntax, namely: 1) problem identification through enculturation of local wisdom; 2) problem solving activities based on local wisdom; 3) reconstruction of findings through assimilation of local wisdom; 4) communicate the results of solving problems scientifically; and 5) process evaluation through acculturation of local wisdom, which is studied theoretically and empirically (Mungmachon, 2013; Pornpimon et al., 2014). The LWIS model developed has been validated and is declared valid based on the content and contruct.

The development of the Local Wisdom Integrated Science (LWIS) is designed to integrate local indigenous cultural communities through enculturation, assimilation, and acculturation 
(Aikenhead, 2006; Pornpimon et al., 2014). Proving the truth of people's cultural knowledge (indigenous knowledge) through experiments and scientific literature studies (scientific knowledge). Automatically there is material from the results of community cultural studies that are integrated in science learning. Cultural integration in science learning is a learning innovation and as a forum for preserving cultural values.

Based on the background, analysis of the problems and solutions offered, the application of the Local Wisdom Integrated Science (LWIS) learning model is carried out by using local Madurese content as a context based on student experiences to train students' scientific literacy. The aim of this study was to evaluate differences in student scientific literacy after applying the the LWIS learning model with local Madurese content in ethnoscience learning.

\section{Research Methods}

This type of research is pre-experimental with a quantitative approach. The research design used one group pretest-posttest. The research was conducted in the even semester of the 2019/2020 academic year. The populations of this study were all students in grade 6A of science education at Trunojoyo University, Madura. The sample used was 22 students selected through purposive sampling technique.

Research procedures include class surveys, preparation of learning tools, development of instruments to measure student scientific literacy in ethnoscience learning with local content in Madura based on the LWIS model, instrument validation, collection of validation results, validity analysis and reliability test data, and data analysis. The research was conducted for 15 meetings on ethnoscience subjects using the LWIS model by utilizing local Madurese content.

The Local Wisdom Integrated Science (LWIS) learning model has 5 syntax, namely: 1) problem identification through enculturation of local wisdom; 2) problem solving activities based on local wisdom; 3) reconstruction of findings through assimilation of local wisdom; 4) communicate the results of solving problems scientifically; and 5) process evaluation through acculturation of local wisdom, which is studied theoretically and empirically (Baynes, R., \& Austin, 2012; Mungmachon, 2013; Pornpimon et al., 2014).

Activities carried out in ethnoscience learning using the LWIS model include discussing the definition and field of ethnoscience studies, the relationship between local Madurese content and ethnoscience, various Madurese local content and research topics with Madurese local content with the instruments, exploration of ethnoscience with local Madurese content in 4 districts on the Madura island, cross-bordering indigenous knowledge to scientific knowledge, cross-bordering proof through literature review and experiments, crossbordering scientific knowledge to indigenous knowledge, integration of ethnoscience into science learning.

The instrument used to collect data was a scientific literacy test. The scientific literacy skills test developed from the aspect of competence consists of 4 indicators, namely using scientific evidence, explaining scientific phenomena, identifying scientific issues, and designing investigations (Bybee, 2011). The tests that have been developed are then validated by experts (Azwar, 2016).

The data collected were checked for normality and homogeneity on the student science literacy exams. The normality test is used to determine whether or not the data is naturally distributed, while the homogeneity test is used to evaluate whether or not the data is homogeneous. The normality test uses the Shapiro-Wilk test and the homogeneity test uses the Levene test, the meaning level of each test is 5 percent (0.05), with the aid of SPSS software version 20. Data is normally and/or homogeneously distributed when the meaning level is 5 percent higher or equal (Sugiyono, 2015).

Following the normality and homogeneity tests on the results of the scientific literacy test data, the researchers conducted a paired sample test to see whether there were discrepancies in the scientific literacy of students before and after studying local content ethnoscience in Madura using the 5 percent (0.05) meaning level LWIS model with SPSS version 20 assistance. The criteria for testing hypotheses testing the paired sample $t$ test, namely if -thitung <ttable < tcount and when the significance level is greater or equal to $5 \%$ then $\mathrm{HO}$ is rejected and $\mathrm{H} 1$ is accepted (Sugiyono, 2015). Calculating the difference between students' scientific literacy before and after learning ethnoscience with local content of Madura using the LWIS model..

The results of calculating the percentage of students' scientific literacy tests are then interpreted by the response category in Table 1. (Nazilah, et al., 2019) 
Table 1. Assessment of students' scientific literacy tests

\begin{tabular}{ll}
\hline Persentage & Category \\
\hline $80,01 \%-100,00 \%$ & Very High \\
$60,01 \%-80,00 \%$ & High \\
$40,01 \%-60,00 \%$ & Moderate \\
$20,01 \%-40,00 \%$ & Low \\
$0 \%-20,00 \%$ & Very Low \\
\hline
\end{tabular}

\section{Result and Discussion}

\section{Validity of Instrumen}

Validation was carried out on a scientific literacy test sheet. The instrument was used to collect scientific literacy data before and after ethnoscience learning with local Madurese content using the LWIS model. The data on the validation results of the scientific literacy test sheet are shown in Table 2.

Table 2. Results of instrument validation

\begin{tabular}{|c|c|c|c|c|c|}
\hline \multirow[t]{2}{*}{ No } & \multirow{2}{*}{$\begin{array}{l}\text { Rated } \\
\text { Aspect }\end{array}$} & \multicolumn{2}{|c|}{$\begin{array}{l}\text { Rating } \\
\text { Score }\end{array}$} & \multirow[t]{2}{*}{ Average } & \multirow[t]{2}{*}{ Category } \\
\hline & & V1 & V2 & & \\
\hline 1 & Format & 4 & 4 & 4 & $\begin{array}{l}\text { Very } \\
\text { Valid }\end{array}$ \\
\hline 2 & Content & 4 & 4 & 4 & $\begin{array}{l}\text { Very } \\
\text { Valid }\end{array}$ \\
\hline 3 & Language & 4 & 4 & 4 & $\begin{array}{l}\text { Very } \\
\text { Valid }\end{array}$ \\
\hline
\end{tabular}

Table 2 shows the results of the validation of the scientific literacy test sheets by two experts showed that the format, content, and language aspects each got a score of 4 and were declared very valid with $100 \%$ reliability (Ratumanan, 2011). These results indicate the scientific literacy test sheet instrument developed is very valid for use.

The Prerequisite Test for Normality and Homogeneity

Student science literacy data were obtained through tests. Student science literacy data that had been collected were tested for normality and homogeneity. The results of the student science literacy data normality test are listed in Table 3.

Table 3. Results of students' scientific literacy normality test

\begin{tabular}{|c|c|c|c|}
\hline \multirow{2}{*}{} & \multicolumn{3}{|c|}{ Shapiro-Wilk } \\
\cline { 2 - 4 } & Statistik & Df & Sig. \\
\hline Pretest & 0,946 & 22 & 0,262 \\
\hline Posttest & 0,948 & 22 & 0,287 \\
\hline
\end{tabular}

Table 3 knows that the pretest significance value is 0.262 and the posttest is 0.287 . This shows that the pretest and posttest significance value is 0.05 , the pretest and posttest variables are said to be normally distributed (Sugiyono, 2015). After it is known that the data is normally distributed, the homogeneity test is carried out. The results of the science literacy data homogeneity test can be seen in Table 4.

Table 4. The results of the students' scientific literacy homogeneity test

\begin{tabular}{ccccc}
\hline \multicolumn{5}{c}{ Test of Homogeneity of Variance } \\
\hline $\begin{array}{l}\text { Levine } \\
\text { Statistic }\end{array}$ & df1 & df2 & Sig. & \\
\hline $\mathbf{0 , 0 1 9}$ & 1 & 62 & 0,891 & Homogeny \\
\hline
\end{tabular}

Table 4 showa a significance value of 0.891 . That is, the significance value is greater than $5 \%$ so that it can be stated that all scientific literacy data provided has a homogeneous variant (Sugiyono, 2015).

\section{Result of Hypothesis Test}

After it was known that the student science literacy data were normally distributed and had homogeneous variants, the researchers conducted a paired sample $t$ test to determine the differences in students' scientific literacy before and after learning ethnoscience with local Madurese content using the LWIS model. Paired sample t test results can be seen in Table 5.

Table 5. Paired sample t test results

\begin{tabular}{|c|c|c|c|c|}
\hline \multicolumn{5}{|c|}{ Paired Sample Test } \\
\hline \multicolumn{2}{|c|}{ Paired Differences } & \multirow[b]{2}{*}{$\mathbf{T}$} & \multirow[b]{2}{*}{ df } & \multirow[b]{2}{*}{$\begin{array}{l}\text { Sig. (2- } \\
\text { tailed) }\end{array}$} \\
\hline Mean & $\begin{array}{c}\text { Std. } \\
\text { Deviation }\end{array}$ & & & \\
\hline$-29,955$ & 10,643 & $-11,878$ & 21 & 0,000 \\
\hline
\end{tabular}

Table 5 shows that the results of tcount (11.878)> $t$ table (2.079). Based on the results of the paired sample $t$ test, then $\mathrm{H} 0$ is rejected and $\mathrm{H} 1$ is accepted. This shows that there are differences in student scientific literacy before and after the application of the LWIS model in ethnoscience learning.

The difference in scientific literacy of students before and after learning ethnoscience with local Madurese content using the LWIS model from the results of test data analysis is also shown in Figure 1. 


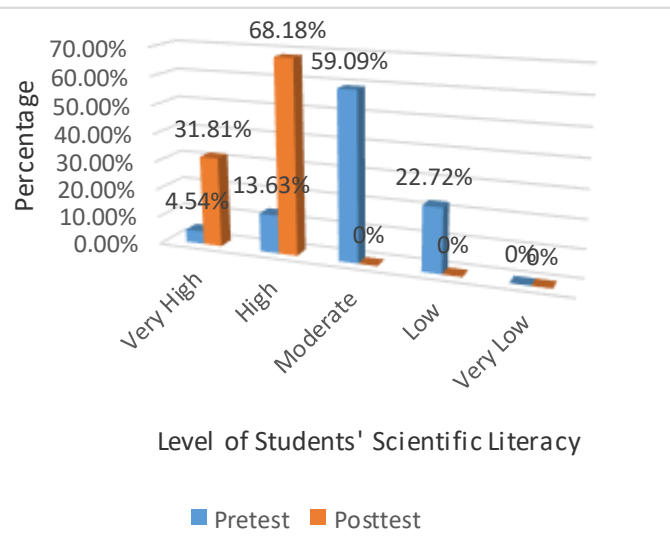

Figure 1. Results of data analysis on scientific literacy

Figure 1 shows that the students' scientific literacy in the pretest results is in the medium category, while the high category is in the posttest results. There are differences in students' scientific literacy when compared in the two categories before and after ethnoscience learning with local Madurese content using the LWIS model. Figure 1 shows that students' scientific literacy at posttest was higher than at pretest. These results indicate that the LWIS model affects students' scientific literacy.

The influence of the LWIS model on students' scientific literacy appears when identifying problems through enculturation of local wisdom from observations and interviews, solving problems based on local wisdom through group discussions, reconstructing findings through assimilation of local wisdom from collaborative concept map making, communicating the results of scientific problem solving, evaluating process through acculturation of local wisdom, which is studied theoretically and empirically (Baynes, R., \& Austin, 2012; Mungmachon, 2013; Pornpimon et al., 2014)..

In learning using the local wisdom integrated science learning model, students carry out these activities following the syntax of local wisdom integrated science learning model, which consists of: 1) identification of problems through the enculturation of local wisdom; 2) problem solving activities based on local wisdom; 3 ) reconstruction of findings through assimilation of local wisdom; 4) communicate the results of solving problems scientifically; and 5) process evaluation through acculturation of local wisdom, which is studied theoretically and empirically (Baynes, R., \& Austin, 2012; Mungmachon, 2013; Pornpimon et al., 2014).

Students make suggestions to the group in a given area of Madura in the first syntax. The students then decided from the observations made a theme / research subject related to community awareness about the local climate, social and cultural factors, which were naturally linked to science learning materials. Students perform group interviews to collect knowledge and public opinion about predetermined topics / themes. The opinion of that group is called indigenous knowledge.

As the community's view, indigenous knowledge isn't inherently valid, so it needs to be checked. Students collect questions during the interview and talk to the public to get as much information as possible. Interviewing activities can support students in practicing scientific literacy effectively (Baynes, R., \& Austin, 2012; Mungmachon, 2013).

In the second syntax, students deliberately address issues based on local knowledge with their community members to solve problems. The solution to the problem is to use empirical knowledge from literature studies and experiments to prove the indigenous knowledge. This research is important to validate, add to, or refute indigenous knowledge. This is important in order to inform the population, so that indigenous knowledge is the population's view, which becomes knowledge whether it is valid or not. In accordance with the opinion of the research results (Gondwe \& Longnecker, 2014; Suastra, 2010; Wagiran, 2011) the proof of local wisdom as truth that has become a tradition in an area is carried out so that people's views and life strategies are not wrong.

In the second syntax, students also indirectly assess science learning materials related to indigenous knowledge and scientific knowledge. Proving indigenous knowledge with scientific knowledge makes students capable and skilled in thinking, both science process skills, critical thinking skills, creative thinking skills, collaboration skills, communication skills, and scientific literacy through a scientific approach (Koizumi, 2017; Kurniawati, 2017; Sudarmin \& Sarmini, 2015).

Students compile the discussion results in the form of an idea map / mind map in the third syntax. The idea map / mind map created reflects a reconstruction of the acquired scientific findings. Making a concept map / mind map is achieved by defining the key concepts and the concepts that help them. The main concept and supporting concepts are connected with conjunctions on the concept map, while the mind map does not use conjunctions. Concept maps are made by students specifically and in depth so that they can know the 
meaning, types, similarities and differences, examples, and concept applications (Mahanal, S., Avila, S., Zubaidah, 2018). The idea map / mind map model is tailored according to each student's interests and imagination. This makes it easier for students to interact and improve scientific literacy (Atay \& Karabacak, 2012; Latif, R. A., Mohamed, R., Dahlan, A., \& Nor, 2016) and create their own understanding and learning more meaningful.

Students review the idea map / mind map made and feedback and suggestions from other classes and lecturers in the fifth syntax. The aim of the assessment is to self-correct the process and the results of the reconstruction of scientific findings which can use scientific knowledge to incorporate, improve or refute indigenous knowledge. Reasons are also required to improve the reconstruction of scientific findings alongside supporting scientific evidence. The assessment findings which were performed are then summarized in the form of a research report in the form of a paper / article / essay / poster. Scientific papers are written in language which is easy to understand.

Students come to the group to provide the science study according to the initial position of the research. Students socialize on the outcomes of the study being done. Socialization is carried out in order to inform the public about the view of the culture that is translated into indigenous knowledge. Student education is useful for incorporating, confirming, explaining or refuting indigenous information using empirical experience, which is supported by justification and scientific evidence.

Students require science knowledge throughout the process of educating the public so that the views and understanding of the people are thorough and easy to understand. This is in line with the view Tatar, E., Tüysüz, C., Tosun, C., \& İlhan (2016); Yusuf \& Adeoye (2012) that scientific literacy is the driver of understanding and student achievement. Scientific literacy includes understanding the communication and application of science by solving current evidencebased problems (Yuliati, 2017; Jurecki \& Wander, 2012). Students can learn their science literacy skills by interacting with friends and the surrounding community (Hanifah \& Julia, 2014; Parmin, 2015). Care using the science learning model combined with local knowledge makes students self-aware of the value of local culture of knowledge and scientific literacy.

In ethnoscience courses the use of local material in science learning links scientific principles and scientific thought in daily life.
Aikenhead (2006), Pornpimon et al. (2014), Sapriadil, S., Setiawan, A., Suhandi, A., Malik, A., Safitri, D., Lisdani, S., Hermita (2018) defines the culture of local wisdom incorporated through 3 items in science learning, namely enculturation, assimilation, and acculturation. Enculturation is the process of learning the cultural values people and cultures encounter. Students reconcile schoolbased science content with the viewpoint they hold by enculturation. The method of enculturation is carried out by making an inventory of the material of science which is in line with local awareness. Therefore the skills of scientific thought will color the way people think.

Assimilation is a mechanism by which cultural elements are shared to overcome the gaps between classes. The process of assimilation may be implemented by combining local culture of knowledge with science. Students study science content that is incompatible with their experience, replacing this viewpoint with a scientific perspective in real life through an assimilation process (Aikenhead, 2006; Pornpimon et al., 2014; Sapriadil, S., Setiawan, A., Suhandi, A., Malik, A., Safitri, D., Lisdani, S., Hermita, 2018).

Acculturation is a social process that arises when a group of people with a certain local wisdom culture is faced with elements of foreign culture. Gradually, foreign cultural elements will be accepted and processed into their own culture without eliminating the original culture. The process of acculturation between science content and local knowledge can be achieved by taking stock of science content that has useful values according to the students and society's history, current, and future needs. Science content is used to substitute old ideas that don't suit the needs or incorporate new ideas based on beliefs, expertise, skills and attitudes of local wisdom. The process of acculturation occurs in the context of local knowledge which may enhance the community's quality of life.

The entire LWIS syntax also helps to incorporate ethnoscience through the STEAM approach to learning. The reconstruction of indigenous knowledge based science results makes students more coordinated and creates freedom (Atmojo, et al., 2019; Dewi, et al., 2019). Alternative methods from the reconstruction of the existing research results are, however, less imaginative and inventive, and of a general sort. Closing this vulnerability is the combination of LWIS and the STEAM method (Science, Technology, Engineering, Art and Mathematics) (Bukhard, et al., 2019; Thibaut, et al., 2018). 
From various STEAM reviews the general Madurese local content is then expanded in detail. The Science analysis stresses the presence of the local content and its constituent materials. Technology emphasizes the local content making processes. Engineering emphasizes the tools / devices that are used to generate local material. Art highlights the qualities of local content. Mathematics stresses the size / dose / concentration of of material used and combined in processes of local processing. STEAM invites students from different disciplinary assessments to become collaborative problem solvers (Messier, 2015; Yakman \& Lee, 2012; Idin, 2018; Colucci, et al., 2017).

\section{Conclusion}

The conclusion of this study is that there are variations between student scientific literacy and local Madurese content using the LWIS learning model before and after ethnoscience learning. The LWIS model helps train students' scientific literacy after learning ethnoscience with local Madurese content by including awareness of the importance of local Madurese content as a learning context and the STEAM approach as a way to integrate ethnoscience into science learning.

\section{Acknowledgement}

The researchers expressed their appreciation for the support of the LPPM, the University of Trunojoyo, Madura, and the Science Education Study Program of Trunojoyo University, which helped facilitate this research.

\section{References}

Aikenhead, G. S. (2006). Science education for everyday life: Evidence-based practice. Science Education, 90(6), 1144-1146. https://doi.org/10.1002/sce.20178

Ameyaw, Y. (2011). Environmental pedagogies that promote students understanding of integrated science (biologi aspect). Journal of Education, $\quad 1(1), \quad 10-15$. http://www.bioinfo.in/contents.php?id =58.

Atay, S., \& Karabacak, Ü. (2012). Care Plans Using Concept Maps and Their Effects on The Critical Thinking Dispositions of Nursing Students. International Journal of Nursing Practice, 18(3), 233-239. https://doi.org/10.1111/j.1440-

172X.2012.02034.x
Amojo, S.E., Kurniawati, W., Muhtarom, T. (2019). Science Learning Integrated Ethnoscience to Increase Scientific Literacy and Scientific Character. Journal of Physics: Conference Series, 1254 (2019) 012033. https://doi.org/10.1088/1742$6596 / 1254 / 1 / 012033$

Azwar, S. (2016). Reliabilitas dan Validitas. PT. Rineka Cipta: Bandung.

Baynes, R., \& Austin, J. (2012). Indigenous Knowledge in the Australian National Curriculum for Science: from Conjecture to Classroom Practice. Paper Presented at the 5 th Biennial International Indigenous Development Research Conference, pp. 1-12. https://core.ac.uk/download/pdf/ 11050305.pdf.

Bozpolat, E. 2016. Investigation of the SelfRegulated Learning Strategies of Students from the Faculty of Education Using Ordinal Logistic Regression Analysis. Journal of Educational Sciences: Theory \& Practice. 16(1), 301-318.

Bukhard, P., Eilerts, K., Filler, A., Pinkwart, N., Rosken-Winter, B., Tiemann, R., Zu Belzen A. U. (2019). A Framework to Foster Problem-Solving in STEM and Computing Education. Research in Science \& Technological Education. 38:1, 105-130, DOI: $10.1080 / 02635143.2019 .1600490$

Bybee, R. (2013). The Teaching of Science: 21st Century Perspective. Journal of Chemical Information and Modeling, 53(9), 16891699. https://doi.org/10.1017/CBO9781107415324. 004

Bybee, R., \& McCrae, B. (2011). Scientific literacy and student attitudes: Perspectives from PISA 2006 science. International Journal of Science Education, 33(1), 7-26.

Colucci, L., Trowsdale, J., Cooke, C. F., Davies, R., Burnard, P.(2017). Reviewing the Potential and Challenges of Developing STEAM Education Through Creative Pedagogies For $21^{\text {st }}$ Learning: How Can School Curricula Be Broadened Towards A More Responsive, Dynamic, and Inclusive Form Of Education? British Educational Research Association.

Dewi, C.A., Khery, Y., Erna, M. (2019). An Ethnoscience Study in Chemistry Learning to Develop Scientific Literacy. Jurnal Pendidikan IPA Indonesia. Vol 8 (2) (2019) 
279-287.

https://doi.org/10.15294/jpii.v8i2.19261

Emda, A. (2017). Kedudukan Motivasi Belajar Mahasiswa dalam Pembelajaran. Lantanida Journal, 5(2), 93-196. https://jurnal.arraniry.ac.id/index.php/ lantanida/article/view/2838/2064.

Genç, M. (2015). The effect of scientific studies on students' scientific literacy and attitude. Ondokuz Mayıs Üniversitesi Eğitim Fakültesi Dergisi, 34(1), 141-152.

Gondwe, M., \& Longnecker, N. (2014). Scientific and Cultural Knowledge in Intercultural Science Education: Student Perceptions of Common Ground. Research in Science Education, 45(1), 117-147. https://doi.org/10.1007/s11165-014-9416-Z

Hasanah, H. (2016). Teknik-Teknik Observasi (Sebuah Alternatif Metode Pengumpulan Data Kualitatif Ilmu-ilmu Sosial). AtTaqaddum, 8(1), 21-46.

Idin, S. (2018). An Overview of STEM Education and Industry 4.0. Research Highlights in STEM Education, 194-208. https://www.isres.org/an-overview-of-stemeducation-and-industry-40-110s.html\#.XzrDYzVS_IU.

Jurecki, K., \& Wander, M. C. (2012). Science literacy, critical thinking, and scientific literature: Guidelines for evaluating scientific literature in the classroom. Journal of Geoscience Education, 60(2), 100-105.

Koizumi, H. (2017). Scientific Learning and Education for Human Security and WellBeing. Springer International Publishing, $6(2), 239-257$. DOI 10.1007/978-3-31947130-3_18.

Kurniawati, A. A., Wahyuni, S., \& Putra, P. D. A. (2017). Utilizing of Comic and Jember's Local Wisdom as Integrated Science Learning Materials. International Journal of Social Science and Humanity, 7(1), 47-50. https://doi.org/10.18178/ ijssh.2017.7.1.793

Latif, R. A., Mohamed, R., Dahlan, A., \& Nor, M. Z. M. (2016). Concept Mapping as a Teaching Tool on Critical Thinking Skills and Academic Performance of Diploma Nursing Students. Education in Medicine Journal, $\quad 8(1), \quad 67-74$ https://doi.org/10.5959/eimj.v8i1.406

Mahanal, S., Avila, S., Zubaidah, S. (2018). Potensi Model Pembelajaran Biologi
Berbasis Reading-Concept Map-Cooperative Script (REMAP-CS) dan Gender Terhadap Keterampilan Berpikir Kritis Mahasiswa SMA Kota Malang. Prosiding Seminar Nasional Pendidikan Biologi, (2006), 186190.

http://jurnalfkip.unram.ac.id/index.php/Semn asBIO/article/viewFile/695/642.

Messier, N. (2015). The How's and Why's of Going 'Full STEAM Ahead' In Your Classroom, Article Steamedu. Online. (Diakses 25 Mei 2020).

Mumthas \& Suneera, A. 2015. Creating SelfRegulated Learners in the Classroom. International Journal of Advanced Research. 3(3), 1039-1042.

Mungmachon, M. R. (2013). Knowledge and Local Wisdom : Community Treasure. International Journal of Humanities and Social Science, 2(13), 174-181. http://www.ijhssnet.com/journals/ Vol_2_No_13_July_2012/18.pdf.

Nastiti, M. (2020). Kesiapan Pendidikan Indonesia Menghadapi Era Society 5.0. Jurnal Kajian Teknologi Pendidikan, Volume 5, No 1, April 2020. page 61-66.

Nazilah, N., Muharrami, L. K., Rosidi, I., Yuniasti, A., \& Wulandari, R. (2019). Pengaruh Bahan Ajar Berbasis Socio-Scientific Issues Pada Materi Pemanasan Global Terhadap Kemampuan Literasi. Natural Sceince Education Reseach, 2(1), 8-16.

Parmin \& Fibriana, F. (2019). Prospective Teachers' Scientific Literacy through Ethnoscience Learning Integrated with the Indigenous Knowledge of People in the Frontier, Outermost, and Least Developed Regions. Jurnal Penelitian dan Pembelajaran IPA, Vol. 5, No. 2, 2019, p. 142-154. https://doi.org/10.30870/ jppi.v5i2.6257.

Pornpimon, C., Wallapha, A., \& Prayuth, C. (2014). Strategy Challenges The Local Wisdom Applications Sustainability in Schools. Procedia - Social and Behavioral Sciences, 112(Iceepsy 2013), 626-634. https://doi.org/10.1016/j.sbspro.2014.01.1210

Ratumanan, G. (2011). Evaluasi Hasil Belajar Pada Tingkat Satuan Pendidikan. Surabaya: Unesa Unversity Press.

Sapriadil, S., Setiawan, A., Suhandi, A., Malik, A., Safitri, D., Lisdani, S., Hermita, N. (2018). Optimizing Students' Scientific Communication Skills Through Higher Order 
Thinking Virtual Laboratory (HOTVL). IOP Conf. Series: Journal of Physics: Conf. Series, $3, \quad 118-126$. https://ui.adsabs.harvard.edu/abs/2018JPhCS 1013a2050S/abstract. Doi: 10.1088/ 17426596/ 1013/1/012050. .

Sasson, I dan Dori, Y. J. (2015). A Three-Attribute Transfer Skills Framework - Part II: Applying and Assessing the Model in Science Education. Journal of Chemistry Education Research and Practice, 6(1), 143 154. https://pubs.rsc.org/en/content/ article landing/2015/rp/c4rp00120f/unauth\#!divAbst ract. DOI: $10.1039 / \mathrm{c} 4 \mathrm{rp} 00120 \mathrm{f}$.

Savelsbergh, E. R., De Jong, T., \& FergusonHessler, M. G. M. (2011). Choosing The Right Solution Approach: The Crucial Role of Situational Knowledge in Electricity and Magnetism. Physical Review Special Topics Physics Education Research, 7(1), 1-12. https://doi.org/10.1103/PhysRevSTPER.7.01 0103

Schwab, K. (2017). The Fourth Industrial Revolution. New York: World Economic Forum.

Suastra, I. W. (2010). Model Pembelajaran Sains Berbasis Budaya Lokal. Jurnal Pendidikan Dan Pembelajaran, 38(3), 377-396. https://doi.org/10.1063/ 1.1635972

Sudarmin. (2014). Pendidikan Karakter, Etnosains dan Kearifan Lokal (Konsep dan Penerapannya dalam Penelitian dan Pembelajaran Sains). Journal of Chemical Information and Modeling, 53(9), 16891699. https://doi.org/10.1017/CBO 9781107 415324.004

Sugiyono. (2015). Statistika untuk Penelitian. Bandung: Penerbit Alfabeta.

Suyono, H. (2011). Belajar dan Pembelajaran Teori dan Konsep Dasar. Bandung: PT Remaja Rosdakarya.

Tatar, E., Tüysüz, C., Tosun, C., \& İlhan, N. (2016). Investigation of Factors Affecting Students' Science Achievement. International Journal of Instruction, 9(2), 153-166. http://www.eiji.net/dosyalar/iji_2016_2_11.pdf. DOI:10.12973/iji.2016.9211a.

Thibaut, L., Ceuppens, S., De Loof, H., De Meester, J., Goovaerts, L., Struyf, A., Boevede Pauw, J., Dehaene, W., Deprez, J., De Cock, M., Hellinckx, L., Knipprath, H., Langie, G., Struyven, K., Van de Velde, D.,
Van Petegem, P. and Depaepe, F. (2018). Integrated STEM Education: A Systematic Review of Instructional Practices in Secondary Education. European Jourrnal of STEM Education, 3(1), 02. https://doi.org/10.20897/ejsteme/85525

Triling, B., \& Fadel, C. (2009). 21st Century Skills: Learning for Life in Our Times. $21 \mathrm{St}$ Century Skill, (Book), 48. https://www.wiley.com/enus/21st+Century+Skills\%3A+Learning+for+ Life+in+Our+Times-p-9781118157060.

Villagonzalo, E. C. (2014). Process Oriented Guided Inquiry Learning: An Effective Approach in Enhancing Students' Academic Performance. The DLSU Research Congress, (2009), $1-6$. https://pdfs.semanticscholar.org/6df4/19f58f5 c2189dc0fb6267f1 fcbdb8dfd6a70.pdf.

Wagiran. (2011). Pengembangan Model Pendidikan Kearifan Lokal Dalam Mendukung Visi Pembangunan Provinsi Daerah Istimewa Yogyakarta 2020 (Tahun Kedua). Jurnal Penelitian Dan Pengembangan $\quad N, \quad 3(5), \quad 85-100$. http://jurnal.pasca.uns.ac.id.

Wibawa, R. P., \& Agustina, D. R. (2019). Peran Pendidikan Berbasis Higher Order Thinking Skills (HOTS) pada Tingkat Sekolah Menengah Pertama di Era Society 5.0 sebagai Penentu Kemajuan Bangsa. Equilibrium, 7(2), 137-141. http://ejournal.unipma.ac.id/index.php/equilibrium/a rticle/view/4779/2266.

Xu, M., David, J. M., \& Kim, S. H. (2018). The Fourth Industrial Revolution: Opportunities and Challenges. International Journal of Financial Research, 9(2), 90-95. https://doi.org/10.5430/ijfr.v9n2p90

Yakman, G., Lee, H. (2012) Exploring the Exemplary STEAM Education in the U.S. as a Practical Educational Framework for Korea. Jornal Korea Science Edu. Vol. 32, No. 6.

Yuenyong, C., \& Narjaikaew, P. (2009). Scientific Literacy and Thailand Science Education. International Journal of Environmental and Science Education, 4(3), 335-349.

Yuliana, I. (2017). Pembelajaran Etnosains untuk Melatihkan Keterampilan Berpikir Kritis Siswa SD. ELSE (Elementary School Education Journal): Jurnal Pendidikan Dan Pembelajaran Sekolah Dasar, 1(2), 98-106. http://journal.um- 
surabaya.ac.id/index.php/pgsd.

Yusuf, F., \& Adeoye, E. (2012). Developing Critical Thinking and Communication Skills in Students: Implications for Practice in Education. An International Multidisciplinary Journal Ethiopia, 6(1), 311-324. https://doi.org/10.4314/ afrrev.v6i1.26 